\title{
フィードバック制御による積乱雲のキーフレームコントロール
}

\section{Keyframe Control of Cumuliform Clouds with Feedback Control}

\author{
楠 元 克 敏†, 正会員 土 橋 宜 典 ${ }^{\dagger}$, 正会員 山本＼cjkstart強 ${ }^{\dagger}$
}

Katsutoshi Kusumoto $^{\dagger}$, Yoshinori Dobashi ${ }^{\dagger}$ and Tsuyoshi Yamamoto ${ }^{\dagger}$

\begin{abstract}
Displaying clouds is one of the important factors in creating images of outdoor scenes by using computer graphics. Methods based on fluid simulations are often used since they can simulate realistic cloud movements and shapes. However, although this approach can create realistic clouds, the resulting shapes and motion depend on many simulation parameters and their initial status. Therefore, it is very difficult to create the clouds of desired shapes. In this paper, we propose a method for generating clouds with shapes that users have specified. The user specifies the multiple shapes of the clouds at several key frames. Then our method automatically adjusts parameters during the simulation in order to generate clouds forming the specified shapes. Using the proposed method, clouds that change into specified shapes can be animated.
\end{abstract}

キーワード：雲，形状変化，フィードバック制御，流体解析

\section{1.まえがき}

3 次元コンピュータグラフィックス $(\mathrm{CG})$ の分野では, 水, 煙，炎などの流体現象を扱ったシミュレーションに関する研 究が注目されている. 従来研究では, 数值流体解析を利用 することで，極めてリアルな映像を生成することに成功し ている ${ }^{1) 2)}$.しかし，数值流体解析による手法では，ユーザ が意図した結果となるようシミュレーションをコントロー ルすることは困難である.この問題点を解消するために, シ ミュレーション過程をコントロールする方法がいくつか提 案されている ${ }^{3) ~ 9)}$. これらの手法では, 煙や水がユーザが 指定した形状となるようコントロールが行われる，本論文 では, 流体現象の中でも雲のコントロールに着目する.

雲は屋外景観の表示において重要な要素であり, 景観シ ミュレーション, コンピュータゲーム, フライトシミュレー 夕など幅広く利用されている. 雲の表示においても, 数值流 体解析を利用することは有効である ${ }^{10)}$. しかし, 生成され る雲の形状や動きは様々な物理パラメータに依存する。そ のため, ユーザが所望する形状の雲が生成されるようこれ らのパラメータを手動で調節することは極めて困難である. この問題を改善するため, 雲の中でも積乱雲の生成に着目 して形状のコントロールを行う方法が提案された ${ }^{11)}$. しか

2008 年 10 月 17 日受付, 2008 年 12 月 22 日再受付, 2009 年 1 月 8 日 採録

$\dagger$ 北海道大学 大学院 情報科学研究科

(广 060-0814 札幌市北区北 14 条西 9 丁目, TEL 011-706-6531)

$\dagger$ Graduate School of Information Science and Technology, Hokkaido University

(Kita14, Nishi9,Kita-ku, Sapporo, 060-0814, Japan)
し，この方法では，単一の目標形状しか指定できないため, 目的の形状の積乱雲が生成された後, 別の形状に変形させ ることはできない.アニメーション作成に㧍いて，時間変 化する屋外景観映像を作成する際，一旦形成された雲がそ の状態のまま留まっている様子は非常に不自然である。そ のため, 例えば, 日中から夕暮れまでの時間変化を伴うア ニメーションを作成する場合，形成された雲が消滅する様 子や形状が変化する様子を表現し, 自然なアニメーション を作成することが必要である。

本論文では，上述の問題を解決するため，文献 11)の手 法を拡張し，複数の目標形状をキーフレームとして指定す ることで, 積乱雲の形状変化が生じるようシミュレーション をコントロールする方法を提案する，提案手法を用いれば， 上述の問題を解決できるだけでなく, 特定のタイミングで 雲が消え去ったり，特定の形状になるなどといった演出効 果を表現することが可能となる。これを実現する単純なア プローチとして, 目的の変化が生じるよう強制的な外力を 付与する方法 ${ }^{3)}$ を用いることが考えられる。しかし，我多 の実験によれば，この方法では積乱雲が水平方向に分裂し て移動するなどの動きが生成されてしまう．積乱雲は，一 般に，上下方向の変化が主であり，このような動きは極め て不自然である. そこで, 提案手法では，一旦，目的の形 状の積乱雲が生成された後, 最初の形状の積乱雲が消滅し ながら，別の形状の積乱雲が新たに生成されると考えるこ とで, 自然な積乱雲のアニメーションを実現する。積乱雲 の生成に関しては，文献 11)の方法を利用し, 積乱雲の消 滅に関しては，新たな手法を開発した。そして，これらを 組み合わせて自然な積乱雲の形状変化を実現する。 
本論文の構成は，以下の通りである，まず，2 節におい て従来手法について議論する． 3 節では，積乱雲のシミュ レーション方法について述べる. 次に, 提案法の基本的考 え方を 4 節で述べた後, 5 節において積乱雲の形状コント ロール手法について詳しく説明する． 6 節では, 提案手法 を用いて生成した適用例を示し，その有効性について検討 する，最後に， 7 節において，本論文のまとめと今後の課 題について述べる.

\section{2. 従 来 研 究}

\section{1 雲のシミュレーション}

CG の分野において雲のモデリングに関する従来研究は 多数行われている. 手続き的ノイズやフラクタルを利用す れば，所望する 3 次元形状を有する雲の密度分布を低コス トで生成できる ${ }^{12)}$. しかし，これらの方法では，雲が生成 される物理現象を考虑していないため, 雲の成長過程を示 すアニメーションや雲の複雑な動きを表現することは困難 である.そこで, 雲の物理現象を考慮した手法が提案されて いる ${ }^{10)}$. この手法では, 大気流体モデルの数值シミュレー ションを行っており,よりリアルな動き・形状の雲を表現 できる．しかし，生成される雲の形状などは入力として指 定する様々な物理パラメー夕に依存するため, ユーザの意 図した形状の雲を生成することは難しい.

\section{2 流体シミュレーションのコントロール}

流体シミュレーションをコントロールする手法は, Treuille らによって初めて提案された ${ }^{3)}$. その後, 効率化を図った 手法 ${ }^{5)}$, 目標形状に応じた外力を用いる手法 ${ }^{4)}$, フィード バック制御を用いる手法 ${ }^{13)}$ など，いくつかの手法が提案 されている.これらの手法により, 煙や水の動きをコント ロールし，動物や文字の形を形成することが可能となって いる．雲のシミュレーションをコントロールする手法とし ては，ユーザが指定した形状に一致した積乱雲が生成され るようコントロールする方法が提案されている ${ }^{11)}$. しかし， この方法では目標とする形状は唯一つであり, 複数の目標 形状を指定して雲の形状変化までコントロールすることは できない。

提案法では, 上述の問題を解決し, キーフレームとして 複数の目標形状を指定することで，ある形状から別の形状 に変化する積乱雲の形状変化アニメーションの生成を可能 とする.

\section{3. 積乱雲のシミュレーション}

積乱雲のシミュレーションには宮崎らの手法 ${ }^{10)} に$ 基づき, 非圧縮性の Navier-Stokes 方程式を文献 14)の手法を用い て数值解析することで行う. シミュレーション空間は $N_{x} \times$ $N_{y} \times N_{z}$ の格子に分割し, 各格子点に速度 $\mathbf{u}=(u, v, w)$, 圧力 $p$, 水蒸気密度 $q_{v}$, 雲密度 $q_{c}$, 温度 $T$ をそれぞれ割り 付ける，以下に，シミュレーションに利用する大気流体モ デルと, 初期条件, 境界条件について示す. 大気は密度が
一定で非圧縮，非粘性の流体であると仮定する，このとき， 大気の速度場は次式の非圧縮, 非粘性の Navier-Stokes 方 程式で表される。

$$
\begin{aligned}
& \frac{\partial \mathbf{u}}{\partial t}=-(\mathbf{u} \cdot \nabla) \mathbf{u}-\frac{1}{\rho} \nabla p+\mathbf{B}+\mathbf{f} \\
& \nabla \cdot \mathbf{u}=0
\end{aligned}
$$

ここで, $\rho$ は大気の密度, $\mathrm{B}$ は浮力, $\mathrm{f}$ は風などの外力を表 す. 浮力 $\mathbf{B}$ は以下の式で表される.

$$
\mathbf{B}=k_{b} \frac{T-T_{a m b}}{T_{a m b}} \mathbf{z}-g q_{c} \mathbf{z}
$$

ここで, $T_{a m b}$ は環境温度, $\mathrm{z}$ は鉛直方向の単位ベクトル, $k_{b}$ は浮力の係数, $g$ は重力の係数である. 環境温度 $T_{a m b}$ は静力学的平衡状態にある大気の温度のことであり, 地面 功の高度に対して, 線形に減少寸る. 式 (3) の右辺第 1 項は, 空気塊の温度と環境温度との差に比例した浮力が発 生することを表し, 右辺第 2 項は水滴の落下にともなう周 辺空気の引きずりを表す.

雲密度 $q_{c}$ と水蒸気密度 $q_{v}$ はそれぞれ次式で表される.

$$
\begin{aligned}
& \frac{\partial q_{c}}{\partial t}=-(\mathbf{u} \cdot \nabla) q_{c}+C_{c} \\
& \frac{\partial q_{v}}{\partial t}=-(\mathbf{u} \cdot \nabla) q_{v}-C_{c}+S_{v} \\
& C_{c}=\alpha\left(q_{v}-q_{s}\right)
\end{aligned}
$$

ここで, $C_{c}$ は相転移によって発生する雲の量, $S_{v}$ は水蒸気 源からの水蒸気の供給量, $\alpha$ は相転移率である. $q_{s}$ は飽和 水蒸気密度を表し, 温度 $T$ の関数として次式で与えられる.

$$
q_{s}=\max \left(A \exp (-B /(T+C)), q_{v}+q_{c}\right)
$$

ここで, $A, B, C$ は飽和水蒸気密度を決定するためのパ ラメータである。

最後に, 温度は以下のように表される。

$$
\frac{\partial T}{\partial t}=-(u \cdot \nabla) T-\Gamma_{d} v_{z}+Q C_{c}+S_{T}
$$

ここで, $\Gamma_{d}$ は乾燥断熱減率, $Q$ は潜熱の係数, $S_{T}$ は熱源 からの熱量を表す.

シミュレーションにおける初期条件と境界条件は以下の ように与える. 初期条件として, 速度は微小乱数により設 定し，雲密度はす心゙ての格子で 0 , 水蒸気密度および温度 は，それぞれ，環境水蒸気密度および環境温度に設定する。 ここで, 環境水蒸気密度は地面からの高度に対して, 指数 関数的に減少するように設定する。境界条件は上下境界で は固定境界条件とし，水平境界では周期境界条件とする。

\section{4. 提案法の基本的な考え方}

提案法では, 複数の目標形状を指定する. 各々の目標形 状は，文献 11）の手法と同様にして指定する.すなわち， ユーザは，スクリーン上で目的とする積乱雲の輪郭線形状 
$\mathrm{t}+1$ 番目の目標形状 $\mathrm{t}$ 番目の目標形状

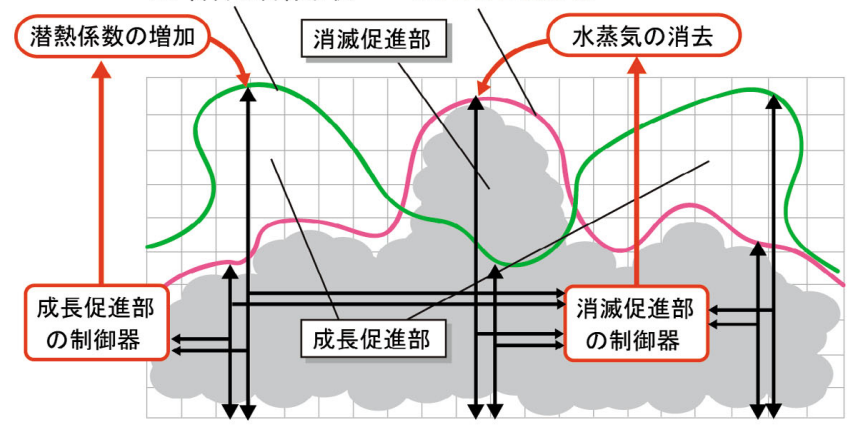

図 1 提案手法の概要

Basic concept behind our method.

を指定する．指定された輪郭形状から，文献 15)の方法に より 3 次元形状を生成する.この 3 次元形状を目標形状と する。

図 1 を用いて提案法の考え方を説明する. 四 1 中の二つ の曲線をそれぞれ $t$ 番目の目標形状, $t+1$ 番目の目標形状 とし, いま, $t$ 番目の目標形状の積乱雲が形成されていると する. 提案法は, 以下の二つのコントロール部分からなる.

- 成長促進部. $t+1$ 番目の目標形状が形成されるよう積 乱雲の成長を促進する. 図 1 に示すように, $t$ 番目の目標 形状の高さより $t+1$ 番目の目標形状の方が高い領域につ いて成長を促す. 具体的には, 文献 11) と同様に, $t+1$ 番 目の目標形状との高さの差に応じて, 潜熱係数を制御する.

- 消滅促進部. $t$ 番目の形状の積乱雲の消滅を促す. 図 1 に示すように, $t+1$ 番目の目標形状より高い位置に存在す る雲の消滅を促す。具体的には, $t+1$ 番目の目標形状との 差に応じて, 水蒸気を強制的に除去することで雲の消滅を 促す.このとき, 成長促進部での雲の成長度合いも監視し, $t+1$ 番目の目標形状が形成されるタイミングにあわせて $t$ 番目の雲が消滅するよう水蒸気の除去量を制御する.

これらの一つの制御を組み合わせることによって，積乱雲 の形状変化を実現する.

\section{5. 積乱雲のコントロール方法}

前節で述べたように，提案法は成長促進部と消滅促進部 からなる。以下，それぞれについて説明する。

\section{1 成長促進部}

成長促進部は，文献 11) の手法を利用する。具体的には， 積乱雲の鉛自方向への発達の促進を潜熱量と水蒸気量を制 御することにより実現する。さらに，より止確に目標形状 の積乱雲を形成するため, 目標形状をもとにポテンシャル フィールドを生成し，目標形状の内部に雲が納まるような 外力を加える。この外力は目標形状の輪郭線付近でのみ発 生する. ポテンシャルフィールドおよび水蒸気量の制御に ついては, 文献 11) と同様であるため, 本稿では詳しい説 明は省略する。以下では, 潜熱量の制御方法についてのみ 説明する。

まず，文献 11）と同様に, 目標形状の高さとシミュレー
ションにより生成される積乱雲の高さとの比率を到達度 $R$ として定義する． $R$ はシミュレーション空間最下層の格子 点 $(i, j, 0)$ ごとに算出する. $R$ は次式により与えられる.

$$
R(i, j)=H_{c}(i, j) / H_{\text {target }}(i, j),
$$

ここで, $H_{c}(i, j)$ はシミュレーションにより生成される各 タイムステップでの雲の高さ, $H_{\text {target }}(i, j)$ は目標形状の 高さを表す. $H_{c}(i, j), H_{\text {target }}(i, j)$ はシミュレーション空 間の最下層からの高さとする. 到達度 $R$ が 1 となるように 潜熱係数 $Q$ (式 8 参照 $)$ を調整することで, 潜熱量を制御す る.ただし， 3 節で述べた雲のシミュレーションでは, 潜 熱係数 $Q$ は全シミュレーション空間で一定であったが, 提 案手法ではシミュレーション空間の最下層の格子点 $(i, j, 0)$ ごとに潜熱係数 $Q_{c}(i, j)$ を定義し，それぞれ，独立に制御 する. 文献 11) では制御方法として PI 制御を用いている が, 本研究では PD 制御を用いる ${ }^{16)}$. PI 制御には制御量と 目標値との差分値を時間的に累積した積分值を制御に利用 するI制御が含まれる。しかし，この方法では，目標形状 が変化する場合, 変更前の制御に利用した積分值が変更後 の制御に影響を及ぼしてしまう。そこで提案手法では，制 御值にあらかじめバイアス值を付加することで, I 制御を 利用することなく残留偏差がなくなるよう制御を行う。ま た, 目標形状が変化する場合, 制御量が急激に変化し, 不 自然な映像となってしまう。これを抑制するためにD 制御 を導入する. PD 制御は, 入力值を出力值と目標の偏差の 1 次関数として制御する比例制御 ( $\mathrm{P}$ 制御) と, 入力值の時 間変化に応じて制御を行う微分制御 (D 制御) を組合せた制 御方法である。P制御により，シミュレーションにより生 成された雲と目標形状との差に比例するよう潜熱量を制御 する。また，D制御により，雲の急激な発達・下降を抑制 し, 不自然な動きとなることを防ぐ. 潜熱係数 $Q_{c}(i, j)$ の 值は, $\mathrm{PD}$ 制御を用いて以下の式により各タイムステップ ごとに決定する。

$$
\begin{aligned}
Q_{c}(i, j) & =K_{P}(i, j) \Delta_{H}(i, j) \\
& +K_{D}(i, j) \frac{d \Delta_{H}(i, j)}{d t}+Q_{c, 0}(i, j) \\
\Delta_{H}(i, j) & =1.0-R(i, j) \\
& =\frac{H_{\text {target }}(i, j)-H_{c}(i, j)}{H_{\text {target }}(i, j)}
\end{aligned}
$$

ここで, $\Delta_{H}(i, j)$ は目標形状の高さとシミュレーションに より生成される雲の高さとの差分を規格化したものである. $K_{P}(i, j), K_{D}(i, j)$ は，それぞれ $\mathrm{P}$ 制御および $\mathrm{D}$ 制御を 調節する值であり, 此例ゲインおよび微分ゲインと呼ばれ る。また， $Q_{c, 0}$ は目標值に達したときにその状態を維持する ための潜熱係数のバイアス值である. $K_{P}(i, j), K_{D}(i, j)$, $Q_{c, 0}(i, j)$ は以下に示すように算出する.

$$
\begin{aligned}
& K_{P}(i, j)=\kappa_{P} H_{\text {target }}(i, j) \\
& K_{D}(i, j)=\kappa_{D} H_{\text {target }}(i, j)
\end{aligned}
$$

論 文 $\square$ フィードバック制御による積乱雲のキーフレームコントロール 


$$
Q_{c, 0}(i, j)=\kappa_{Q 0} H_{\text {target }}(i, j)
$$

$\kappa_{P}, \kappa_{D}, \kappa_{Q 0}$ は, 限界感度法 ${ }^{17)}$ により実験的に決定す る. なお, $Q_{c}(i, j)$ は鉛直方向 $(z$ 軸成分 $)$ にすべて同一の 值を用いる. また, $\mathrm{PD}$ 制御により算出した $Q_{c}$ が 0 以下 となる場合，雲が減少するときに潜熱が発生してしまうた め, $Q_{c}=0$ とすることで不自然な映像となることを防ぐ.

\section{2 消滅促進部}

消滅促進部は水蒸気密度, 重力, 温度場を制御すること により実現する。これらの制御を行うことで，雲の消滅お よび鉛直下方向への下降を促す. 以下，それぞれの具体的 な制御方法と作用について説明する。

まず, 水蒸気密度の制御については, 目的形状の外部に 存在する領域について, 水蒸気量を強制的に徐々に減少さ せる.これにより, 対象領域の空気が乾燥し, 雲 (水滴) か ら水蒸気への相転移が生じ, 雲が消滅する。このとき, 水 蒸気を全体で一様に減少させるのではなく, 雲の一番高い 位置から消去する。これらにより，雲が徐々に低くなりな がら自然に消滅する映像を表現できる。水蒸気量の減少は 以下の式で表現する。

$$
q_{v}\left(i, j, k_{\text {top }}\right)=D_{\text {rate }} \times q_{v}\left(i, j, k_{\text {top }}\right)
$$

ここで, $\left(i, j, k_{t o p}\right)$ は，はシミュレーションにより生成され る雲の一番高い位置に相当する格子点であり, $D_{\text {rate }}$ は水 蒸気量の減衰率である. 前述したように, $t+1$ 番目の雲が 形成されるとタイミングに合わせて $t$ 番目の雲が消滅する よう $D_{\text {rate }}$ を以下に示すように制御する. まず, $t+1$ 番目 の目標形状と, 雲の高さとの差分をとり, 目標値まで達し ていない領域での差分の平均值を $R_{u p}$ および目標值を超え た領域での差分の平均值を $R_{\text {down }}$ を, それぞれ, 以下の式 により算出する。

$$
\begin{aligned}
& R_{u p}=\frac{1}{N_{u}} \sum_{l=1}^{N_{x}} \sum_{m=1}^{N_{y}}\left(H_{\text {target }}(l, m)-H_{c}(l, m)\right) \\
& R_{\text {down }}=\frac{1}{N_{d}} \sum_{l=1}^{N_{x}} \sum_{m=1}^{N_{y}}\left(H_{c}(l, m)-H_{\text {target }}(l, m)\right)
\end{aligned}
$$

ここで, $N_{u}, N_{d}$ は，それぞれ，シミュレーション空間の 最下層の格子点について, 目標値まで達していない領域内 に存在する格子点および目標值を越えた領域内に存在する 格子点の総数である.これらの值を利用し, 以下のように $D_{\text {rate }}$ を決定する.

$$
D_{\text {rate }}=1.0+C_{r} \times\left(R_{\text {up }}-R_{\text {down }}\right)
$$

ここで, $C_{r}$ は制御の影響度を調節するための係数であり， 水蒸気消去係数と呼ぶ. この制御を行うことで, 雲の発達 と雲の消滅を同じ割合で促進させることが可能である. 水 蒸気の制御のみを適用して生成した雲の形状変化の出力結 果について図 $2(b)$ に示す. 図 $2(a)$ は図中の曲線を $t$ 番目 の目標形状とし, 提案手法を用いてシミュレーションした
結果である. 図 $2(b)$ は, $t$ 番目の目標形状の雲を形成後, $t+1$ 番目の目標形状として図中の曲線を指定し, シミュ レーションを行った結果である. 出力結果からわかるよう に, 水蒸気の消去のみでは $t+1$ 番目の目標形状を超えた 位置に雲が残存してしまっている。この問題点を改善する ために, 重力の制御を行う. 重力の制御も考慮し, 雲を鉛 直方向に下降させながら水蒸気を消去することで，雲が上 空に残るような映像となることを抑制することが可能であ る. 具体的には, 式 (3) の右辺第 2 項を次式で表される $G_{c}$ により置き換えることで，重力の制御を行う.

$$
\begin{aligned}
& G_{c}=g_{c} q_{c} \mathbf{z} \\
& g_{c}(i, j, k)=\left(k-H_{\text {target }}(i, j)\right) \times g_{e x}+g
\end{aligned}
$$

ここで, 式 (18) で表される $g_{c}$ は, 日標值に遠い位置ほど より多くの重力が作用するよう制御する． $g_{e x}$ は重力の制 御を調整するための係数であり, 過㮃重力制御係数と呼ぶ. また, $k$ は $\mathrm{z}$ 軸方向の格子点番号である. 図 $2(c)$ は水蒸気 の制御に加え, 重力の制御を適用して生成した雲の形状変 化の出力結果である. 図 $2(a)$ に示す $t$ 番目の目標形状の 雲を形成後, $t+1$ 番目の目標形状の雲を生成するようシ ミュレーションを行った，水蒸気のみの制御である図 $2(b)$ と比較すると改善が見られるものの, 図 $2(c)$ の真ん中付近 に雲が目標形状まで下降していない部分が存在する。これ は, 重力の制御の効果により一度目標形状まで雲が下降す るが, その後, 不要な浮力が働き, 雲が再度目標形状を超 えて上昇したために起こる。この浮力は重力の制御による 雲の落下に伴い, 温度も同様に落下し, 制御位置の底面付 近に高い温度が集約するために発生する，そこで，重力の 制御範囲に㧍ける温度場を徐々に環境温度まで減少するよ う制御することで，底面付近に高い温度場が発生すること を抑制する，温度場の制御に利用する式は以下のように与 える.

$$
\frac{\partial T}{\partial t}=E_{r}\left(T_{a m b}-T\right)
$$

ここで, $E_{r}$ は温度場を環境温度に近づける割合を調節する ための係数であり, 温度減衰率とする. 温度場の支配方程 式 (8)に加えて, 式 (19) を考虑したシミュレーションを行 うことで，タイムステップごとに徐々に温度場が環境温度 に近づくよう制御する。この制御により，重力の作用によ る高温の温度場が発生することを抑制し，不自然な浮力の 発生が改善される. 四 $2(d)$ に温度の制御も考慮してシミュ レーションを行った結果を示す. 温度の制御により, 浮力 の問題が解消され，一度目標形状まで下降した雲は上昇す ることなく目標形状付近に留まる。

\section{6. 実 験 結 果}

本節では提案手法の適用例を示し，その有效性につ いて検討する。実装環境は CPU として Intel Core2 


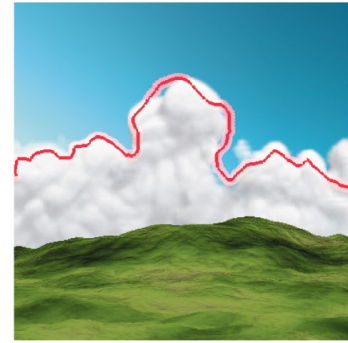

(a) 提案法による $\mathrm{t}$ 番目の形状

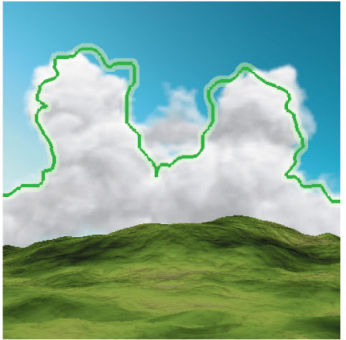

(b) 水蒸気の制御

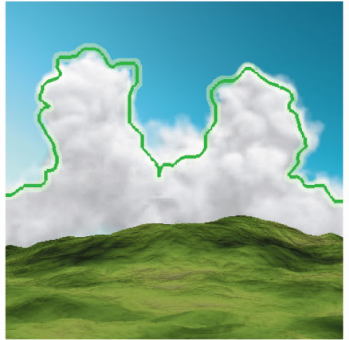

(c) 水蒸気 + 重力の制御

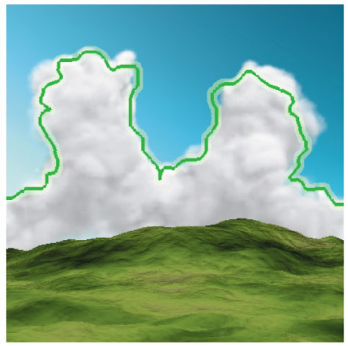

(d) 水蒸気 + 重力 + 温度の制御

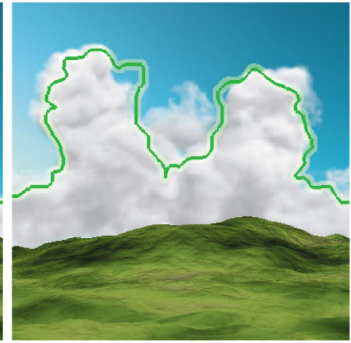

(e) 従来法 (土橋らの手法)

図 2 異なる制御方法での比較例

Comparison of cloud using different control method.

Duo E6750，グラフィックスハードウェアとして NVIDIA Geforce7600GS を搭載した PC である。グラフィックス APIには OpenGL を用いた。雲の表示には, シミュレー ション空間の各格子の雲密度分布より文献 18) の手法を利 用してレンダリングを行った。 まず，提案手法の有効性を 示すため土橋らの手法 ${ }^{11)}$ を用いて生成した例を図 $2(e)$ に 示す. 図 $2(a)$ は前述したように, $t$ 番目の目標形状が形成 されるよう提案手法を用いて生成した結果， $(d),(e)$ はそ れぞれ $t+1$ 番目の目標形状を生成するために提案手法を 適用した結果, 土橋らの手法 ${ }^{11)}$ を適用した結果である. 図 $2(e)$ の出力結果ついても, 図 $2(a)$ 中の曲線を $t$ 番目の夕ー ゲット, 図 $2(b)$ 中の曲線を $i+1$ 番目のターゲットとして シミュレーションを行った。 シミュレーションで用いた格 子数は $120 \times 80 \times 100$ である. 提案手法を用いて生成した画 像では, $t$ 番目のターゲットから $t+1$ 番目のターゲットへ 雲を鉛直方向に発達させる領域，下降させる領域ともに目 標形状通りに到達している。制御に用いたパラメータには 表 1 に示した值を用いた。一方, 従来手法 ${ }^{11)}$ を用いて生 成した結果では, 発達させる領域は目標形状付近まで到達 しているが, 下降させる領域については, 目標形状よりも 上空に残存した結果となってしまう。.以上から，提案手法 を用いることにより，従来手法では不可能であったキーフ レームでの雲の形状変化コントロールが可能となったこと がわかる. 次に，提案手法を用いてキーフレームとして三 つの目標形状を指定して生成した雲の形状変化のアニメー ション過程について図 3 に示す. 図 $3(a),(b),(c),(d)$, $(e),(f)$ はそれぞれ，140，160，180，200，230，260step 目の結果を表示したものである. 図 $3(a),(c),(e)$ 中の曲 線がそれぞれ 1 番目, 2 番目, 3 番目の目標形状である. シ ミュレーションで用いた格子数は $200 \times 80 \times 100$ であり, 1 ステップあたりのシミュレーション時間は 6.95 秒であり, そのうち, 消滅促進部の処理に要する時間は 0.03 秒であっ た。消滅促進部による処理速度の低下はほとんどないこと がわかる. 図 4(a)，(b)，(c) はそれぞれ図 $3(b),(d),(f)$ の曲線を表示しない場合の適用例である。また，図 $4(d)$, $(e),(f)$ は図 $4(a),(b),(c)$ と同じ雲であるが, レンダリ ング時に太陽の高度を低くした場合の出力結果である.太 陽の位置を変更させることにより, 雲の色を変更させるこ
表 1 実験に用いた制御パラメー夕数值 Control parameter value.

\begin{tabular}{c||c|c}
\hline \hline & パラメータ名 & 数值 \\
\hline \hline$C_{r}$ & 水蒸気消去係数 & 2.0 \\
\hline$g_{e x}$ & 過剩重力制御係数 & 6.5 \\
\hline$E_{r}$ & 温度減哀率 & 0.97 \\
\hline
\end{tabular}

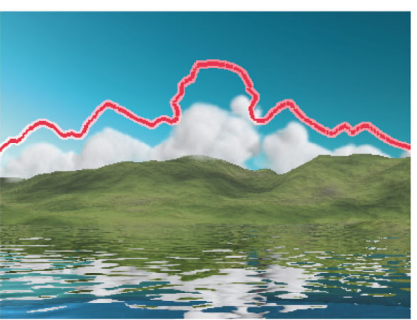

(a) 140step

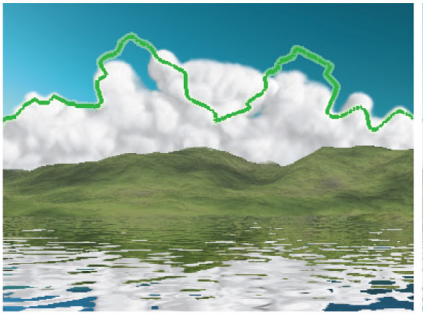

(c) 180step

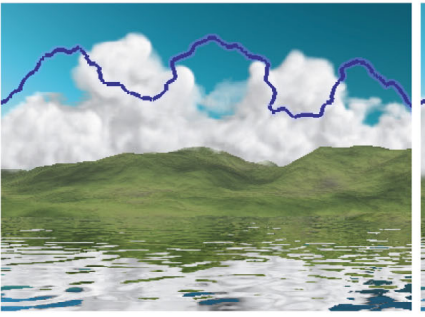

(e) 230 step

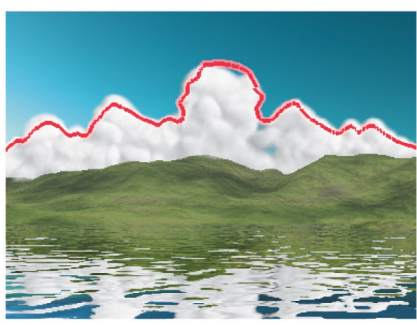

(b) 160 step

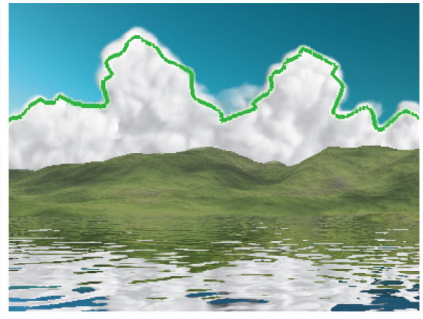

(d) 200 step

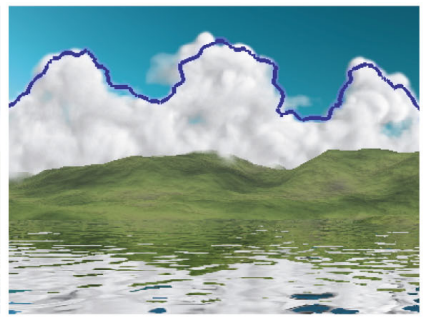

(f) 260step

\section{図 3 適用例}

Example.

とが可能である.また， 3 次元シミュレーションを行って いるため, 視点を変更させた場合の出力結果も得ることが できる，提案手法により，輪郭線を指定するだけで，様々 な形状の積乱雲を生成することが可能であり，シミュレー ション中に輪郭線を変更することにより, 雲の形状変化ア ニメーションの生成も可能である. 本節で示した雲の形状 や，雲の形状変化アニメーションをシミュレーションパラ メータの調整で生成することは極めて難しい. 


\section{7. まとめと今後の課題}

本論文では，キーフレームとして指定した形状変化が生 じるよう積乱雲のシミュレーションをコントロールする方 法を提案した．形状変化を実現するため，雲の成長に加え て，雲の消滅も制御する方法を提案した，提案手法では, $\mathrm{PD}$ 制御により雲の生成過程をコントロールし, 水蒸気・温 度・重力をコントロールすることで雲の消滅を実現した。

今後の課題として, 積乱雲だけでなく, 巻積雲, 高積雲 など層状の雲の形状コントロール方法の開発が考えられる. 提案手法では，これらの雲の生成に必要なべナール対流 ${ }^{19)}$ を考慮していないため,コントロールにはベナール対流を 考慮する必要がある.

\section{〔文献〕}

1) N. Foster and R. Fedkiw: "Practical animation of liquids", SIGGRAPH '01: Proceedings of the 28th annual conference on Computer graphics and interactive techniques, ACM, pp. 23-30 (2001)

2) D. Q. Nguyen, R. Fedkiw and H. W. Jensen: "Physically based modeling and animation of fire", ACM Trans. Graph., 21, 3, pp. $721-728(2002)$

3) A. Treuille, A. McNamara, Z. Popovi' c and J. Stam: "Keyframe control of smoke simulations", SIGGRAPH '03: ACM SIGGRAPH 2003 Papers, ACM, pp. 716-723 (2003)

4) R. Fattal and D. Lischinski: "Target-driven smoke animation", SIGGRAPH '04: ACM SIGGRAPH 2004 Papers, ACM, pp. 441-448 (2004)

5) A. McNamara, A. Treuille, Z. Popović and J. Stam: "Fluid control using the adjoint method", ACM Trans. Graph., 23, 3, pp. 449-456 (2004)

6) J.-M. Hong and C.-H. Kim: "Controlling fluid animation with geometric potential: Research articles", Comput. Animat. Virtual Worlds, 15, 3-4, pp. 147-157 (2004)

7) N. Thürey, R. Keiser, M. Pauly and U. Rüde: "Detail-preserving fluid control", SCA '06: Proceedings of the 2006 ACM SIGGRAPH/Eurographics symposium on Computer animation, Eurographics $\Lambda$ ssociation, pp. 7-12 (2006)

8) Y. Kim, R. Machiraju and D. Thompson: "Path-based control of smoke simulations", SCA 06 : Proceedings of the 2006 ACM SIGGRAPH/Eurographics symposium on Computer animation, Eurographics Association, pp. 33-42 (2006)

9) B. Kim, Y. Liu, I. Llamas, X. Jiao and J. Rossignac: "Simulation of bubbles in foam with the volume control method", SIGGRAPH ' 07: ACM SIGGRAPH 2007 papers, ACM, p. 98 (2007)

10) R. Miyazaki, Y. Dobashi and T. Nishita: "Simulation of cumuliform clouds based on computational fluid dynamics", EUROGRAPHICS 2002 Short Presentations, pp. 405-410 (2002)

11) Y. Dobashi, K. Kusumoto, T. Nishita and T. Yamamoto: "Feedback control of cumuliform cloud formation based on computational fluid dynamics", ACM Trans. Graph., 27, 3 (2008)

12) D. S. Ebert, F. K. Musgrave, D. P. nad Ken Perlin and S. Worley: "Texturing modeling: a procedural approach", Morgan Kaufmann Series in Computer Graphics and Geometiric Modeling.

13) L. Shi and Y. Yu: "Taming liquids for rapidly changing targets", SCA , 05: Proceedings of the 2005 ACM SIGGRAPH/Eurographics symposium on Computer animation, ACM, pp. 229-236 (2005)

14) J. Stam: "Stable fluids", SIGGRAPH '99: Proceedings of the 26th annual conference on Computer graphics and interactive techniques, ACM Press/Addison-Wesley Publishing Co., pp. 121128 (1999)

15) T. Igarashi, S. Matsuoka and H. Tanaka: "Tcddy: a skctching interface for 3d freeform design", SIGGRAPH '99: Proceedings of the 26th annual conference on Computer graphics and interactive techniques, ACM Press/Addison-Wesley Publishing Co., pp. 409-416 (1999)

16) F. Haugen: "Pid control of dynamic systems", Tapir Forlag".

17) B. J. ZIEGLER and N. B. NICHOLS: "Optimum settings for automatic controllers", Transactions of the A. S. M. E. 64, pp. 759-768 (1942)

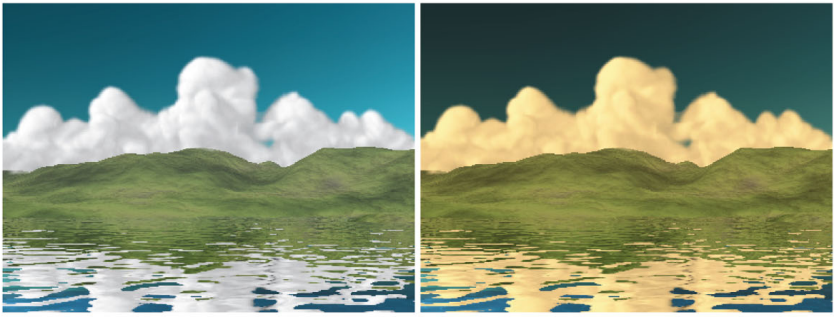

(a)

(d)

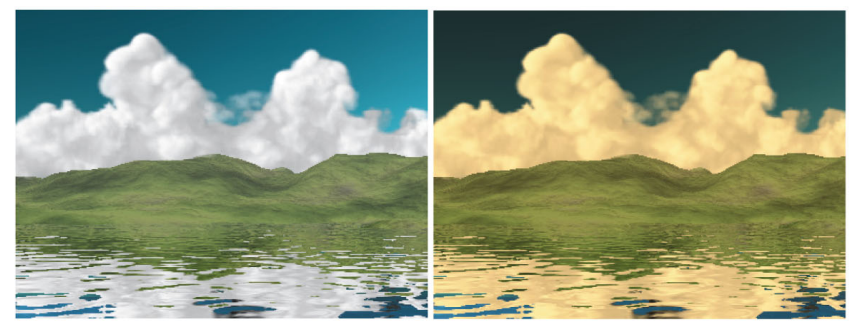

(b)

(e)

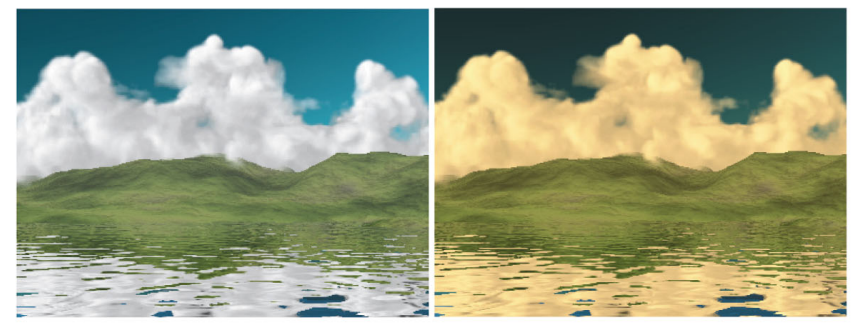

(c)

(f)

図 4 適用例 (世線の描画なし)

Example(no target shapes).

18) Y. Dobashi, K. Kaneda, H. Yamashita, T. Okita and T. Nishita: "A simple, efficient method for realistic animation of clouds", SIGGRAPH '00: Proceedings of the 27th annual conference on Computer graphics and interactive techniques, ACM Press/Addison-Wesley Publishing Co., pp. 19-28 (2000)

19) R. Miyazaki, S. Yoshida, T. Nishita and Y. Dobashi: "A method for modeling clouds based on atmospheric fluid dynamics", PG '01: Proceedings of the 9th Pacific Conference on ComputerGraphics and Applications, IEEE Computer Society, pp. 363-372 (2001)

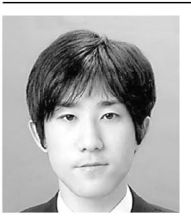

糈然 克敏 2006 年, 北海道大学工学部卒業. 現 在, 同大大学院情報科学研究科修士課程に在学中. 主と して, コンピュータグラフィックスに関する研究に従事。

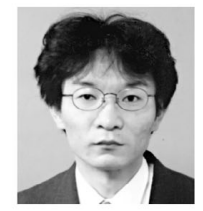

どば喬皆貿 1992 年, 公島大学工学部卒業. 1994 年, 同大学大学院工学研究科博士課程前期修了. 1997 年, 同博十課程後期修了. 同年, 広島市立大学情報科学部助 手. 2000 年, 北海道大学大学院工学研究科助教授. 2004 年, 同大学大学院情報科学研究科助教授. 主として, コ ンピュータグラフィックスに関する研究に従事. 博士 (工 学). 正会員.

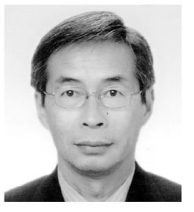

热毕胎 1976 年, 北海道大学工学部卒業. 1978 年, 同大学大学院工学研究科修士課程修了. 1982 年 3 月, 同博士課程中退. 1982 年, 同大学工学部講師. 1986 年, 同助教授. 1999 年, 同大学大学院工学研究科 教授. 2004 年, 同大学大学院情報科学研究科教授. 工 学博士. 主として, デー夕放送, マルチメディア, コン ピュータグラフイックス, 並列処理に関する研究に従事。 